A N N A L E S

UNIVERSITATIS MARIAE CURIE-SKŁODOWSKA

LUBLIN - POLONIA

VOL. XXXIV

SECTIO FF

$2-2016$

\title{
ŁUKASZ RZEPKA
}

Uniwersytet Papieski Jana Pawła II w Krakowie

\section{„Wielka rzeź Armagedonu”. O czasach końca w publikacjach Towarzystwa Strażnica}

"Great slaughter of Armageddon". About the times of the end in the Watch Tower Society publications

Oprócz obrazów świata postapokaliptycznego prezentowanych w literaturze czy kinematografii science fiction funkcjonują również takie, które mają realny wpływ na życie jednostki czy grupy społecznej oraz projekcje wyobraźni religijnej. Jednym z takich utopijnie zorientowanych wyznań jest wyjątkowo mocno wpisany w nurt chiliastyczny Chrześcijański Zbór Świadków Jehowy¹. Należąca do kręgu badaczy Pisma Świętego powstała w XIX wieku grupa w głoszonej nauce wskazuje na tysiącletnie panowanie Chrystusa Króla, które rozpoczęło się w 1914 roku. W swoich publikacjach Towarzystwo Strażnica często

${ }^{1}$ Towarzystwo Strażnica nie podaje nazwisk autorów ani miejsc wydania publikacji, dlatego o ile nie zaznaczono inaczej, zapis według wzoru: tytuł, rok wydania oraz numer strony, podane w przypisie oznaczać będą wydawnictwa książkowe Świadków Jehowy. Różnorodność datacji czasopism „Strażnica” wynika ze zmian, które zachodziły na przestrzeni lat. Początkowo podawano numer dwutygodnika. Po 12. numerze z 1988 r. wprowadzono podział na datację dzienną i miesięczną, np. 1 lipca i 15 lipca. W 2008 r. podzielono wydania na te do rozpowszechniania (R) oraz edycję do studium (S) dla członków organizacji. Stąd trzy rodzaje zapisu bibliograficznego np.: (1) 1970, nr 1; (2) 1986, 1 stycznia; (3) 2009, 15 lutego (S). Od 2016 r. zaprzestano podawania dat dziennych, w wydania (R) wprowadzono numerację ciągłą, a w edycji (S) zachowano jedynie nazwę miesiąca. „Przebudźcie się” do 2005 roku ukazywało się jako dwutygodnik, obecnie jest to miesięcznik. Skrót „PNŚ" przy siglach biblijnych oznacza, iż cytat pochodzi z polskiego thumaczenia Pisma Świętego z Przekładu Nowego Świata, wydawanego w ramach ogólnoświatowej działalności ewangelizacyjnej organizacji.

Confer: J. Piegza, Świadkowie Jehowy. Geneza i struktura kontestacji religijnej, Kraków 1994, s. 28-30. 
stara się dowieść, że żyjemy w czasach ostatecznych, na co wskazują konflikty zbrojne, wszechobecna przemoc, upadek moralności. Spróbujemy przyjrzeć się tym prekognicjom i rewelacjom. Analiza treści religijnych stanowi wyjątkowe pole badawcze, ponieważ perswazyjny tekst oddziałuje tutaj w realny sposób na człowieka, w odróżnieniu od fikcji literackiej czy filmowej, którym czytelnik/widz nie podporządkowuje - tak bezwarunkowo - swojego życia jak właśnie wierze i jej emanacji w religijnym kulcie.

Świadkowie Jehowy to trzeci pod względem liczebności związek wyznaniowy w Polsce ${ }^{2}$. W publikacjach autorzy należący do organizacji podają, iż początków działalności Badaczy Pisma Świętego w Polsce należy upatrywać już pod koniec XIX wieku, kiedy w 1891 roku do Krakowa przybył Charles T. Russell - pierwszy prezes Towarzystwa ${ }^{3}$. Podstawę prawną Badacze uzyskali 20 maja $1913 \mathrm{roku}^{4}$. W kolejnych dziesięcioleciach działalność wspólnoty była wielokrotnie zakazywana. Ponowna legalizacja miała miejsce 12 maja 1989 roku, wówczas w oficjalnej nazwie użyto określenia, które Badacze przyjęli już w 1931 roku $^{5}$ „Świadkowie Jehowy”. W akcie rejestracji prawnej (nr: II-803/14/16/89) w Urzędzie do Spraw Wyznań widniała nazwa: Strażnica - Towarzystwo Biblijne i Traktatowe. Zarejestrowany Związek Wyznania Świadków Jehowy ${ }^{6}$. Z kolei zmiana statutu wyznania z 13 maja 2014 roku podaje skróconą wersję nazwy: „Świadkowie Jehowy w Polsce"

Temat artykułu „Wielka rzeź Armagedonu” pochodzi z książki Światto autorstwa Josepha F. Rutherforda, drugiego prezesa Towarzystwa Strażnica, wydanej w $1930 \mathrm{roku}^{8}$. Poniżej zostaną zaprezentowane treści oraz poglądowy materiał ikonograficzny w następującym porządku: (1) dni ostatnie, (2) Armagedon, (3) Tysiącletni Dzień Sądu, czyli (3a) nowe niebo, (3b) nowa ziemia. Artykuł nie rości sobie prawa do polemiki międzywyznaniowej czy apologii którejkolwiek konfesji chrześcijańskiej, ma na celu jedynie przekrojową analizę szczególnego rodzaju świata post-apo głoszonego przez Świadków Jehowy. Ze względu na pojawiające się tzw. „nowe światło”, czyli kolejne zmiany doktrynalne, nierzadko wykluczające dotychczasową wykładnię, koniecznym jest przedstawienie również tych różnic, by prezentowany obraz był całościowy.

${ }^{2}$ Średnia liczba aktywnych głosicieli w roku 2015 wynosiła 122 021; confer: „Rocznik Świadków Jehowy" 2016, s. 178-187.

${ }^{3}$ Confer: The Watchtower Announcing Jehovah's Kingdom, 1892, s. 1370.

${ }^{4}$ Confer: Reskrypt nr 2167/5 wydany przez Wincentego Kina - generała-gubernatora Warszawy; W. Tyloch, Leksykon religioznawczy, Warszawa 1988, s. 256-257.

${ }^{5}$ Confer: Królestwo Boże panuje, 2014, s. 73.

${ }^{6}$ Confer: T. Mędzelowski, Mniejszości religijne w Polsce po 1989 roku w ujęciu filozofii polityki, Tarnów 2013, s. 28.

${ }^{7}$ Confer: Decyzja Ministra Administracji i Cyfryzacji RP z dnia 13 maja 2014 r.

${ }^{8}$ Confer: J. F. Rutherford, Światto, t. II, Nowy Jork 1930, s. 184. 


\section{DNI OSTATNIE}

Organizacja Świadków Jehowy akcentuje ostateczność świata, w ich nomenklaturze „złego systemu rzeczy”, w którym żyjemy. Powszechnie znany jest fakt wielokrotnego podawania przez Towarzystwo Strażnica daty końca świata. Temu zagadnieniu w literaturze przedmiotu poświęcono wiele miejsca ${ }^{9}$, dlatego wystarczy przypomnieć tylko kilka z proponowanych dat: $1914^{10}, 1925^{11} \mathrm{czy} 1975^{12}$ rok. Niezrealizowane proroctwa wymusiły niejako na Ciele Kierowniczym ustosunkowanie się do tych zapowiedzi, dlatego w „Strażnicy” z 2013 roku podano: „Świadkowie Jehowy mieli niekiedy mylne oczekiwania co do nadejścia końca [...], tak bardzo pragnęliśmy spełnienia proroctw, że wyprzedzaliśmy Boży harmonogram wydarzeń..."13.

Prezentowane daty miały wskazywać na moment nie tylko niewidzialnego przyjścia Chrystusa, ale również początku Armagedonu. Dalej w tekście miesięcznika potwierdzono oczekiwanie zbliżającego się końca. To wypatrywanie „wielkiej rzezi” oraz wskazywanie na okoliczności ją zwiastujące pojawia się w zdecydowanej większości publikacji, ponieważ stanowi jedną z podstawowych prawd doktrynalnych, wykładanych również zainteresowanym w czasie odwiedzin domowych. „Dni ostatnie” zdaniem Towarzystwa rozpoczęły się w roku $1914^{14}$, kiedy Jezus objął władzę w Królestwie Bożym. W pierwszych publikacjach wskazywano na rok 1874, z czasem jednak pojawiło się „nowe światło", które pozwoliło na skorygowanie daty. Została ona ustalona na podstawie wyliczeń pierwszych prezesów Towarzystwa Biblijnego i Traktatowego Strażnica. Jezus po wniebowstąpieniu ,czekał na rozkaz Jehowy”"15, by móc rozpocząć panowanie oraz przeprowadzić powzięte przez Boga zamiary. „Pierwszym jego posunięciem po objęciu królowania w niebie było strącenie w pobliże ziemi Szatana i popierających go demonicznych aniołów" ${ }^{16}$. Razem z tymi wydarzeniami nastał bardzo trudny czas dla wyznawców. Już Apostołowie mieli bacznie obserwować otoczenie, by dzięki temu rozpoznać, „co będzie znakiem obecności Chrystusa oraz zakończenia systemu rzeczy” (confer: Mt 24, 3 PNŚ). W jednej

\footnotetext{
${ }^{9}$ Confer: W. Bednarski, W obronie wiary, Torun 2015, s. 351-357.

${ }^{10}$ Confer: Ch. T. Russell, The Time is at Hands, Allegheny 1907, s. 101; W. Bednarski, ,,Pokolenie roku 1914" i oczekiwania Świadków Jehowy, b.m. 2015.

${ }^{11}$ Confer: J. F. Rutherford, Miliony z obecnie żyjacych nie umra, Warszawa 1920, s. 76; W. Bednarski, Rok 1925 i „Miliony ludzi z obecnie żyjących nigdy nie umra!”, Szydłówek-Toruń-Gdańsk 2015.

${ }^{12}$ Confer: Dlaczego oczekujesz roku 1975?, „Strażnica” 1969, nr 5, s. 8. Confer: W. Bednarski, Armagedon w 1975 roku ,,możliwy” czy ,prawdopodobny”?, Tychy 2009.

${ }^{13}$ Koniec świata - strach, fascynacja i rozczarowanie, „Strażnica” 2013, 1 stycznia (R), s. 8.

${ }^{14}$ Prowadzenie rozmów na podstawie pism, 2001, s.73.

${ }^{15}$ Będziesz mógt żyć wiecznie w raju na ziemi, 1990, s. 68.

${ }^{16}$ Wiedza, która prowadzi do życia wiecznego, 1995, s. 99.
} 
z publikacji podano cechy charakterystyczne, które potwierdzają, iż żyjemy w czasach realizowania się ostrzeżeń biblijnych, wymieniono w niej m.in.: wojny, klęski głodu i zarazy, wzrost bezprawia, rujnowanie ziemi ${ }^{17}$.

Przez kilka dziesięcioleci organizacja, powołując się na słowa Jezusa (Mt 24, 34), nauczała, że pokolenie, które żyło w 1914 roku będzie świadkiem końca. W książce wydanej w języku polskim w 1984 roku o znamiennym tytule Będziesz mógł żyć wiecznie w raju na ziemi zapisano:

Które pokolenie miał na myśli [Jezus - uzup. Ł. R.]? Pokolenie, które już żyło w 1914. Żyjący jeszcze członkowie tego pokolenia są już bardzo starzy. A przecież przynajmniej niektórzy z nich mają jeszcze żyć, gdy ten zły system się skończy. Możemy więc być pewni, że wkrótce nastąpi w Armagedonie koniec wszelkiego zła i wszystkich złych ludzi ${ }^{18}$.

\section{ARMAGEDON}

Greckie słowo har magedòn, przejęte z języka hebrajskiego i oddawane przez wielu thumaczy jako „Armagedon”, znaczy „góra Megiddo” lub „góra zgromadzenia wojsk". Jak podaje leksykon biblijny Wnikliwe poznawanie Pism: „Biblia nie łączy tej nazwy $\mathrm{z}$ zagładą nuklearną, tylko z nadchodzącą powszechną «wojną wielkiego dnia Boga Wszechmocnego» (Obj 16:14,16)"'19. Armagedon ma być zatem wielką bitwą, w której przeciwko Bogu Jehowie zgromadzą się władcy i armie wszystkich narodów. W niej ulegną zagładzie ziemskie królestwa, a także nieprzestrzegający zasad Boga Jehowy oraz niewyznający wiary w niego, co będzie równoznaczne $\mathrm{z}$ wiecznym unicestwieniem.

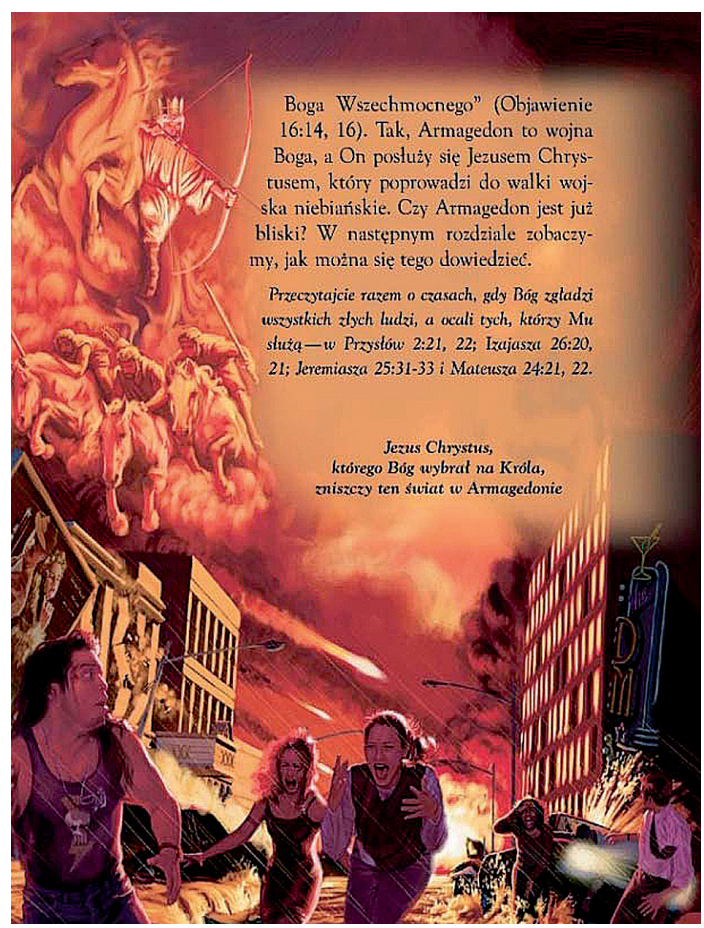

Ucz się od Wielkiego Nauczyciela, 2003, s. 243

W przedstawieniach ikonograficznych Towarzystwa Armagedon ukazywany jest jako dramatyczne wydarzenie, w którym Bóg ześle na jego przeciwników

${ }^{17}$ Confer: ibidem, s. 98-107.

${ }^{18}$ Będziesz mógł żyć wiecznie..., s. 154.

${ }^{19}$ Confer: Wnikliwe poznawanie pism, t. I, 2006, s. 783-785. 
wielkie cierpienie. Miesięcznik „Przebudźcie się” opisuje ten moment jako „dzień napawający lękiem”: „Biblia w przejmujący sposób opisuje czas, gdy ziemia będzie pokryta zwłokami zabitych, pozostawionymi niczym «gnój na powierzchni roli» i jako pożywienie dla ptaków oraz innych..."20.

Na szczególną uwagę zasługuje ilustracja z książki przeznaczonej dla dzieci Ucz się od Wielkiego Nauczyciela, która ma pomóc rodzicom w przystępny sposób przedstawić potomstwu życie Jezusa i podstawowe nauki organizacji ${ }^{21}$. Prezentowany w niej obraz Armagedonu pozwala odczytać kilka rysów zasadniczych tego wydarzenia.

1. Na czele boskiej armii stać będzie królujący Chrystus, przy boku którego będą walczyć aniołowie oraz pomazańcy, tj. ci, którzy zostali wybrani do grupy 144000 mających panować z Jezusem w nowym niebie ${ }^{22}$. Żyjący w czasie Armagedonu wyznawcy Jehowy są zaproszeni do „obejrzenia rozmiarów tej rzezi”’23 ${ }^{\prime 2}$ jednak nie będą brali udziału w tej bitwie ${ }^{24}$.

2. Po lewej stronie przedstawiono bilbord lub ekran, na którym widnieje reklama filmu (?) akcji, na co wskazywać może broń trzymana przez kobietę i mężczyznę. Obok narysowano budynek w momencie burzenia, a przed nim zadaszenie z literami „XXX”. Po przeciwnej stronie ulicy widać płonący budynek z reklamą baru lub dyskoteki. Obraz ten ma wskazywać na unicestwienie niegodziwych rozrywek oraz pornografii.

3. Ulicę zalewa coś w rodzaju „ognistej wody”, w której brodzą przedstawiciele różnych grup etnicznych, religijnych i narodowych. Druga osoba od lewej, kobieta, ma na szyi krzyżyk, co wskazywałoby na wyznawców nominalnego chrześcijaństwa, którzy również mają zostać zgładzeni.

4. Całość utrzymana jest w tonacjach koloru czerwonego i pomarańczowego, a jasne kreski i kule, czyli deszcz ognia i siarki ma być nawiązaniem do zagłady Sodomy i Gomory.

Inne przedstawienia zachowują powyższą estetykę ${ }^{25}$. Ocaleni rozpoczną etap wzmożonej pracy, mającej na celu usunięcie pozostałości po Armagedonie, po

\footnotetext{
${ }^{20}$ Czy Armagedonu trzeba się bać?, „Przebudźcie się” 2005, 8 lipca, s. 12-13.

${ }^{21}$ Ucz się od Wielkiego Nauczyciela, 2003, s. 243.

${ }^{22}$ Confer: Królestwo Boże panuje, 2014, s. 228.

${ }^{23}$ Poktadajmy ufność w Jah, Jehowie!, „Strażnica” 1988, nr 11, s. 16.

${ }^{24}$ Confer: Armagedon - radosny początek, „Strażnica” 2005, 1 grudnia, s. 6.
}

${ }^{25}$ Ze względu na ograniczenia formalne analizie został poddany tylko jeden przykład. Podobny materiał ikonograficzny prezentują również: Oddawaj cześć jedynemu prawdziwemu Bogu, 2002, s. 76, 180-181; Rozkoszuj się życiem wiecznym, 1987, s. 13; Jak powstało życie? Przez ewolucje czy stwarzanie?, 1989, s. 234-235; Wspaniały finat Objawienia jest bliski!, 1993, s. 52, 233, 285; Wiedza, która prowadzi do życia wiecznego, 1995, s. 100-101; Czego naprawdę uczy Biblia?, 2005, s. 83. 
którym „nic nie pozostanie z tego złego świata”26. Miliony wyznawców zamieszkają wówczas na nowej ziemi, a 144000 pomazańców w nowym niebie będzie królowało razem z Chrystusem.

\section{NOWE NIEBO}

Świadkowie Jehowy często powołują się na werset z Apokalipsy Jana: „I ujrzałem nowe niebo i nową ziemię; bo poprzednie [...] przeminęły” (Obj 1, 21 PNŚ). Jest to kluczowy fragment dla doktryny o realizacji boskiego planu dotyczącego ziemi i człowieka. Początkowo Jehowa stworzył ludzi do życia w raju na ziemi, jednak po grzechu pierwszych rodziców pierwotne zamierzenie nie mogło być zrealizowane. Bóg nie odrzucił jednak swoich planów, a dokonał zmiany w sposobie ich wypełnienia. Jednym z takich planów było ustanowienie niebiańskiego rządu, na czele którego stanie jego Syn - Jezus, a którego zadaniem będzie przygotowanie, mówiąc ściśle przywrócenie do stanu pierwotnego, ziemi, by ta stała się przestrzenią wiecznego życia ludzkości. Konieczne zatem było dokonanie wyboru odpowiedniej liczby kobiet i mężczyzn ${ }^{27}$, mających stać się „,nowym stworzeniem" ${ }^{28}$ przez zrodzenie z ducha świętego do żywej nadziei ${ }^{29}$. Zostali oni bowiem wykupieni z ziemi, spośród ludzi ,jako pierwociny dla Boga i dla Baranka" (Obj 14, 3-4 PNŚ).

Wybór takiej osoby dokonuje się w kilku etapach, z których wstępne realizuje Bóg, pozostałe zaś uzupełnić musi pomazaniec. To Jehowa uznaje powoływanego chrześcijanina za prawego, ,rodzi go do nowego życia”, czyli zalicza w poczet duchowych synów, chrzci w śmierci Chrystusa, wreszcie namaszcza i uświęca. Natomiast do obowiązków powołanego należy wierne realizowanie powołania i wybrania, wytrwanie w niezachwianej lojalności aż do śmierci, by dzięki temu uzyskać wskrzeszenie do życia duchowego ${ }^{30}$.

Dokładna liczba powołanych została podana w Apokalipsie: „Usłyszałem liczbę tych, których opieczętowano: sto czterdzieści cztery tysiące” (Obj 7, 4 PNŚ). Kompletowanie tej grupy rozpoczęło się za czasów apostolskich, jednak - jak podaje „Strażnica” - „potem najwyraźniej zostało spowolnione. Niemniej było kontynuowane przez kolejne stulecia aż do naszych czasów [...]. Sprawy nabrały tempa, gdy w roku 1914 Jezus objął władzę"31. Proces ten trwa, dlatego kolejne osoby mogą się cieszyć otrzymaniem nadziei niebiańskiej ${ }^{32}$. Na uwagę

\footnotetext{
${ }^{26}$ Będziesz mógt żyć..., s. 155.

${ }^{27}$ Confer: Wiedza, która prowadzi do życia wiecznego, 1995, s. 88; Bóg ma dla nas Dobra No-
} wine, 2012, s. 14.

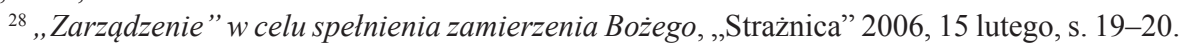

${ }^{29}$ Confer: Radujmy się w nadziei, ,Strażnica” 2012, 15 marca (S), s. 21.

${ }^{30}$ Confer: Wnikliwe poznawanie Pism, t. II, 2006, s. 178.

${ }^{31}$ Poczytani za godnych otrzymania Królestwa, „Strażnica” 2008, 15 stycznia (S), s. 22.

${ }^{32}$ Confer: Czy otrzymateś ,,ducha prawdy”?, „Strażnica” 2002, 1 lutego, s. 20. 
zasługuje również wzmianka dotycząca wskrzeszenia do niebiańskiej funkcji pierwszych pomazańców - zdaniem organizacji dokonało się to między rokiem 1918 a $1935^{33}$, mają oni bowiem udział w tzw. „pierwszym zmartwychwstaniu”, które nastąpiło - i trwa nadal - w momencie objęcia przez Jezusa władzy w nie$b_{i}{ }^{34}$. W odróżnieniu od „wielkiej rzeszy”, mającej nadzieję na „nowe ciało fizyczne”, pomazańcy po zmartwychwstaniu otrzymają „,nowe ciało duchowe”35.

Nie można upatrywać tutaj rodzaju ścisłej predestynacji z tytułu przynależności do tzw. „ostatka”, ponieważ niemoralność życia oraz sprzeciwianie się wymaganiom Jehowy prowadzi do usunięcia jednostki z grupy pomazańców. W miejsce odsuniętej od godności królewskiej osoby wybierana jest kolejna ${ }^{36}$. Należy bowiem pamiętać, iż „powołanie niebiańskie, które ktoś otrzymuje, jest jedynie zaproszeniem, a nie ostatecznym potwierdzeniem nagrody"37. Warto jedynie nadmienić, iż w ostatnich latach widać wzmożoną publikację tekstów dotyczących „pomazańców”, co jest ściśle związane z liczbą osób przyjmujących emblematy podczas Pamiątki, obchodzonej przez świadków czternastego dnia miesiąca Nissan. Jak naucza organizacja, jedynie posiadający pewność wybrania do grupy królów mogą spożywać mace i czerwone wino, symbolizujące ciało i krew Jezusa.

Znakiem rozpoznawczym „małej trzódki” będzie wypisane na czołach imię Baranka oraz imię Ojca - Jehowy ${ }^{38}$. Będą oni pełnić funkcje kapłańskie ${ }^{39}$, a ich głównym zadaniem, oprócz śpiewania nowej pieśni przed Tronem, stanie się sprawowanie nadzoru nad pracami prowadzonymi na rajskiej ziemi. Wszystkie bowiem działania mające na celu przywrócenie naszej planecie pierwotnego stanu będą realizowane zgodnie ze wskazówkami i poleceniami pochodzącymi z nowych niebios ${ }^{40}$.

\section{NOWA ZIEMIA}

Sielankowa wizja nowej ziemi kreowana przez Towarzystwo Strażnica, nie urzeczywistni się bezpośrednio po doświadczeniach Armagedonu. Przerażającą wizję snują autorzy „Strażnicy”: „Po Armagedonie ci, którzy przeżyją, będą oglądać zwłoki zabitych przez Jehowę. Tych będzie ponad dwa miliardy! [...] Tych zwłok nikt nie będzie grzebał. Staną się pastwą robaków, ptaków i innych

\footnotetext{
${ }^{33}$ Confer: Poczytani za godnych otrzymania Królestwa, „Strażnica” 2002, 1 lutego, s. 20.

${ }^{34}$ Confer: Oddawaj cześć jedynemu prawdziwemu Bogu, 2002, s. 84.

${ }^{35}$ Confer: Radujmy się w nadziei, s. 22.

${ }^{36}$ Confer: „Stale podązaja za Barankiem”, „Strażnica” 2009, 15 lutego (S), s. 24; Wnikliwe poznawanie Pism, t. I, 2006, s. 545.

${ }^{37}$ Confer: „Pójdziemy z wami”, „Strażnica” 2016, nr 1 (S), s. 23.

${ }^{38}$ Confer: Wnikliwe poznawanie Pism, t. I, s. 420.

${ }^{39}$ Confer: ibidem, s. 126.

${ }^{40}$ Confer: Będziesz mógt żyć..., s. 165.
} 
zwierząt..."41. Choć bogobojni wyznawcy nie zaznają cierpienia podczas tych wydarzeń, ich obowiązek to oczyszczenie zgliszcz i ruin starego „systemu rzeczy”, które pozostaną po bitwie ${ }^{42}$; będzie to jednak „mnóstwo przyjemnej pracy", jak podała jedna z publikacji ${ }^{43}$. Nowa ziemia nie będzie zatem nową planetą, ale rodzajem nowej społeczności ludzkiej, która chroniona przez Boga i dzięki jego dobrodziejstwu będzie wiodła szczęśliwy żywot pod panowaniem Jezusa i współkrólów.

Obraz ludzkości na nowej ziemi można rozpatrywać w odniesieniu do (1) Boga i niebiańskiego rządu, (2) bliźnich i (3) zwierząt. Życie człowieka w okresie tysiącletniego panowania odzyska utraconą doskonałość, choć nie będzie to jeszcze doskonałość rajska pierwszych rodziców. Dalszy proces poznawania prawdy o Jehowie dokona się przy pomocy nie tylko znanej współcześnie Biblii (Przekład Nowego Świata), ale również dzięki nowym pismom - „księgom zawierającym prawa i pouczenia" ${ }^{44}$. Polecenia kierowane z nowego nieba zostaną wypełnione pod nadzorem wiernych mężczyzn - nazwanych „książętami”"45, czyli swego rodzaju przedstawicieli Królestwa na ziemi. Nadal będzie prowadzona ogólnoświatowa działalność ewangelizacyjna, bowiem „nawet ci, którzy umarli, będą się mogli rozkoszować rajską ziemią. Powrócą do życia!" "46. Szczególnie ciekawą wydaje się koncepcja radosnych przekazów, rozpowszechnianych wśród ludzi. Towarzystwo podaje, iż ,zamiast nekrologów będą publikowane radosne wiadomości o zmartwychwstałych" "47. Do życia na rajskiej ziemi zostaną wskrzeszeni nie tylko sprawiedliwi, ale również „niesprawiedliwi”, tzn. niemający za życia możliwości opowiedzenia się za Prawdą, jak również ci, którzy kierowali się moralnością i nie zgrzeszyli przeciwko duchowi świętemu ${ }^{48}$. Nie zostaną wskrzeszeni ludzie, którzy po śmierci trafili bezpośrednio do Gehenny, symbolizującej wieczną zagładę, a nie do Hadesu, ponieważ kto rozmyślnie odrzuca panowanie Jehowy, „nie może liczyć na zmartwychwstanie” ${ }^{49}$. Przywrócenie do życia nie stanie się jedynie prostym powrotem do starego ciała, gdyż ono - jak podaje Towarzystwo - „najprawdopodobniej się rozłożyło i powróciło do ziemi”"50, ale będzie to wskrzeszenie „osoby”, której Bóg ofiaruje „,nowe ciało fizyczne”, podobne do poprzedniego, by bliscy mogli je poznać. Aby zrozumieć sensow-

${ }^{41}$ Trzy światy. Świat ówczesny, świat teraźniejszy, nadchodzacy świat, „Strażnica” 1959, nr 14, s. 19.

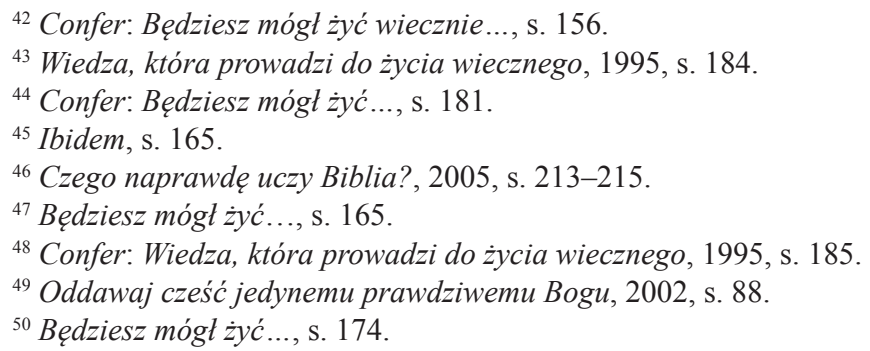


ność zmartwychwstania niesprawiedliwych po Armagedonie, należy wyraźnie nakreślić wizję Dnia Sądu prezentowaną przez Świadków Jehowy. Nie jest to bowiem jednorazowe dla każdego człowieka wydarzenie, podczas którego wskrzeszony staje przed Tronem Boga i zdaje relację ze swojego życia. Jak podaje jedna z publikacji: ,[Bóg - uzup. Ł. R.] wbrew utartym wyobrażeniom nie będzie sądził ludzi na podstawie dawnych grzechów popełnionych nieraz nieświadomie. Biblia wyjaśnia, że śmierć uwalnia człowieka od wszystkich grzechów" ${ }^{\prime 51}$.

Dzień Sądu to tysiącletni okres, podczas którego ludzie nieznający dotychczas prawdy o Bogu będą mieli sposobność jej poznania oraz opowiedzenia się za nią ${ }^{52}$. Sprzeciwienie się normom Jehowy zakończy się jednak wiecznym unicestwieniem jednostki albo w czasie Dnia Sądu, albo najpóźniej przy jego końcu. Osoby respektujące zakazy oraz wypełniające nakazy Boga pod koniec Dnia Sądu osiągną „ludzką doskonałość”, którą posiadali przed grzechem rajskim pierwsi ludzie.

Nowe niebo ma być wyjątkową społecznością ludzi, cieszącą się: pokojem, brakiem wojen, zapewnionymi warunkami mieszkaniowymi i ciekawą pracą, brakiem przestępczości czy przemocy, obfitością dobrej żywności dla wszystkich, braterstwem ludzkości, pokojem między człowiekiem a dzikim zwierzęciem, brakiem chorób, zatrzymanym procesem starzenia się, a nawet jego odwróceniem, ustaniem śmierci i wreszcie przywróceniem do życia umarłych. Życie rodzinne osiągnie zamierzony przez Boga poziom, który będzie polegał na miłości i oddaniu się drugiej osobie. Doktryna Towarzystwa zakłada również, iż po Armagedonie nadal będą rodzić się dzieci, również u par, które za czasów „złego systemu rzeczy" nie mogły ich posiadaćs ${ }^{3}$. O idealnym życiu jednostki oraz relacjach dzięki temu budowanym organizacja pisze w sposób przekonujący szczególnie dla tych, którzy obecnie borykają się z problemami wynikającymi z ludzkiej ułomności. Warto przytoczyć dłuższy fragment:

Z czasem znikną wszelkie choroby [...]. Ułomni i kulawi będą mogli stać, chodzić, biegać i tańczyć na zdrowych, silnych nogach. Po latach życia w świecie ciszy głusi usłyszą rozbrzmiewające wokół nich radosne odgłosy. Niewidomi zaczną z zachwytem podziwiać bogactwo kolorów i kształtów, które ukaże się ich oczom [...]. Nareszcie ujrzą twarze swych bliskich! Być może na krótko zamglą im wtedy wzrok łzy radości.

Pomyśl tylko! Nie będą już potrzebne okulary, kule ani laski, lekarstwa, przychodnie dentystyczne ani szpitale! Depresje i inne zaburzenia emocjonalne na zawsze przestaną ograbiać ludzi ze szczęścia. Już nikomu choroba nie zmarnuje dzieciństwa. Usunięte zostaną przykre skutki starości [...]. Staniemy się zdrowsi i silniejsi [...].

\footnotetext{
${ }^{51}$ Ibidem, s. 175.

${ }^{52}$ Confer: ibidem, s. 178.

${ }^{53}$ Confer: Będziesz mógt żyć..., s. 181.
} 
Na ludzi przeprowadzonych żywo przez Armagedon będzie czekać mnóstwo przyjemnej pracy. Zaczną przekształcać ziemię w raj. Usuną wszelkie ślady po starym skażonym systemie. Zamiast slumsów i śmietnisk pojawią się ogrody i parki. Wszyscy zamieszkają w wygodnych, ładnych domach... ${ }^{54}$

Nową ziemię zamieszkają również inne stworzenia - wszelkiego rodzaju ryby, płazy, gady, ptaki i ssaki. Będą one jednak usposobione pokojowo. Świadkowie snują idylliczną wizję: „Jakże przyjemnie będzie wtedy pospacerować po lesie i przez chwilę pobyć w towarzystwie lwa albo wielkiego niedźwiedzia!"'55. Z wizji przyszłego raju wynika, iż będą w nim żyć wegetarianie lub weganie, ponieważ, jak podaje jeden z opisów: „Zamiast bezsensownie zabijać [zwierzęta, ludzie - uzup. Ł. R.] otoczą je należytą opieką" ${ }^{56}$. Opis wilka pasącego się z barankiem lub lwa z cielętami pozwala wysunąć jasny wniosek dotyczący zmiany, która nastąpi w sposobie odżywiania się zoofagów.

Dzień Sądu zakończy się ostateczną próbą. Poddani jej zostaną wszyscy ludzie, po tym jak „Jehowa wypuści Szatana i jego demony z przepaści”, w której przebywali przez tysiąc lat. Nielojalni wobec Boga zostaną wówczas wrzuceni do „symbolicznego «jeziora ognia», którym jest wtórna [wieczna - uzup. Ł. R.] śmierć" ${ }^{57}$. Jako ostatni wróg zostanie pokonana śmierć. Kiedy opisane powyżej wydarzenia zrealizują się, Jezus ostatecznie odda władzę Ojcu, „Syn podporządkuje się temu, który mu wszystko podporządkował, tak by Bóg był wszystkim dla każdego" (1 Kor 15, 28 PNŚ).

Idylla kreowana przez organizację wzbudza jednak pewne obiekcje wśród wyznawców, czego dowodem może być pytanie jednego z czytelników, zadane na łamach „Strażnicy”: „Czy życie wieczne w raju nie będzie nudne?”, na które odpowiedź niestety jest tylko powtórzeniem dotychczas głoszonej nauki o nowej ziemi (satysfakcjonująca praca, przyjazne towarzystwo, poznawanie prawdy o Bogu $)^{58}$.

\section{ZAKOŃCZENIE}

Wizja świata postarmagedonowego prezentowanego przez Świadków Jehowy jawi się jako kraina szczęśliwości, której ideę ofiarowania jej ludzkości Stwórca posiadał już w momencie powoływania do życia pierwszego człowieka. Adam i Ewa sprzeniewierzyli się swojemu Bogu, przez co pierwotny plan musiał zostać zrealizowany w inny sposób. To dobrowolna ofiara życia Jezusa -

\footnotetext{
${ }^{54}$ Wiedza, która prowadzi..., s. 183-184.

${ }^{55}$ Będziesz mógt żyć..., s. 164.

${ }^{56}$ Wiedza, która prowadzi..., s. 184.

${ }^{57}$ Ibidem, s. 183.

${ }^{58}$ Confer: Czy życie w raju będzie nudne?, „Strażnica” 2011, 1 maja (R), s. 27.
} 
pierworodnego Syna Ojca - pozwoliła, by cel ziemskiego raju mógł zostać osiągnięty przez ludzkość. Doktryna Towarzystwa Strażnica diametralnie różni się od wyznawanej przez nominalne chrześcijaństwo. Dowodem tego jest również proklamowana perspektywa wieczności Królestwa Niebiańskiego, którego panowanie rozpoczęło się w 1914 roku. Eschatologiczna retoryka organizacji szczególnie może oddziaływać na osoby samotne, cierpiące czy chore, borykające się z problemami codziennego życia. Kreowana wizja nowej ziemi, na której przywracane będą utracone na przestrzenie wieków rajskie cechy, wpisuje się w ogólnoludzkie tęsknoty za światem pokoju i braterskiej miłości. Aby jednak mogła ona nastać, ze świata muszą zostać usunięci niegodziwi przedstawiciele obecnie panującego ,złego systemu rzeczy” wraz z religiami fałszywymi, które wielu prowadzą do zatracenia. Zaskakiwać może wykorzystanie kategorii zastępczego bożego „rządu”, sprawującego władzę nad ludzkością zamieszkującą planetę. Pragmatycznie rzecz ujmując, wydaje się, iż dla osób niebędących Świadkami Jehowy lepsza perspektywa to niepoznawanie ich doktryny. Dzięki temu, jeśli życie nie będzie pozbawione moralności oraz pragnienia poznania istoty wyższej, dana osoba zostanie wskrzeszona na nowej ziemi i potwierdzi prawdziwość nauki. Pozostaje jedynie mieć nadzieję, iż ,wielka rzeź Armagedonu” nie stanie się naszym udziałem.

\section{BIBLIOGRAFIA}

Adamczyk H., Organizacja. Dzieje działalności i przemian, Głogów 2010.

Armagedon - radosny początek, „Strażnica” 2005, 1 grudnia.

Bednarski W., ,Pokolenie roku 1914” i oczekiwania Świadków Jehowy, b. m. 2015.

Bednarski W., Armagedon w 1975 roku ,,możliwy” czy ,prawdopodobny”?, Tychy 2009.

Bednarski W., Rok 1925 i „Miliony ludzi z obecnie żyjących nigdy nie umrą!”, Szydłówek-Toruń-Gdańsk 2015.

Bednarski W., W obronie wiary, Torun 2015.

Będziesz mógt żyć wiecznie w raju na ziemi, 1990.

Bóg ma dla nas Dobrą Nowine, 2012.

Czego naprawdę uczy Biblia?, 2005.

Czy Armagedonu trzeba się bać?, „Przebudźcie się” 2005, 8 lipca.

Czy otrzymateś ,, ducha prawdy”?, „Strażnica” 2002, 1 lutego.

Czy życie w raju będzie nudne?, „Strażnica” 2011, 1 maja (R).

Dlaczego oczekujesz roku 1975?, „Strażnica” 1969, nr 5.

Grzywa J., Religijność Świadków Jehowy w Polsce, „Nomos” 1998, nr 22/23.

Jak powstało życie? Przez ewolucję czy przez stwarzanie?, 1989.

Jaroś E., Eschatologiczny wymiar języka w polskich publikacjach Świadków Jehowy, [w:] Język tożsamości, red. G. Cyran, E. Skorupska-Raczyńska, Gorzów Wielkopolski 2015.

Koniec świata - strach, fascynacja i rozczarowanie, „Strażnica” 2013, 1 stycznia (R).

Koniec świata, „Przebudźcie się” 2015, nr 11.

Królestwo Boże panuje, 2014.

Oddawaj cześć jedynemu prawdziwemu Bogu, 2002. 
Piegza J., Świadkowie Jehowy. Geneza i struktura kontestacji religijnej, Kraków 1994.

Poczytani za godnych otrzymania Królestwa, „Strażnica” 2002, 1 lutego.

Poczytani za godnych otrzymania Królestwa, „Strażnica” 2008, 15 stycznia (S).

Poktadajmy ufność w Jah, Jehowie!, „Strażnica” 1988, nr 11.

Popiół-Wojciechowska P., Wizja Armagedonu przedstawiana przez organizację Strażnica - Towarzystwo Biblijne i Traktatowe (Zarejestrowany Związek Wyznania Świadków Jehowy), [w:] Powodzie, plagi, życie i inne katastrofy, red. K. Konarska, P. Kowalski, Wrocław 2012.

„Pójdziemy z wami”, „Strażnica” 2016, nr 1 (S).

Prowadzenie rozmów na podstawie pism, 2001.

Radujmy się w nadziei, „Strażnica” 2012, 15 marca (S).

Radujmy się z zaślubin Baranka!, „Strażnica” 2014, 15 lutego (S).

Rataj M., Wizja przyszłości świadków Jehowy, „Przegląd Religioznawczy” 2001, nr 1.

Rozkoszuj się życiem wiecznym na ziemi!, 1987.

Russell Ch. T., Dokonana Tajemnica, Nowy Jork 1925.

Russell Ch. T., The Time is at Hands, Allegheny 1907.

Rutherford J. F., Miliony z obecnie żyjacych nie umra, Warszawa 1920.

Rutherford J. F., Światto, t. II, Nowy Jork 1930.

„Stale podązaja za Barankiem”, „Strażnica” 2009, 15 lutego (S).

Świadkowie Jehowy-głosiciele Królestwa Bożego, 1995.

The Watchtower Announcing Jehovah's Kingdom, 1892.

Trzy światy. Świat ówczesny, świat teraźniejszy, nadchodzacy świat, „Strażnica” 1959, nr 14.

Tyloch W., Leksykon religioznawczy, Warszawa 1988.

Uchan J., Obraz człowieka w doktrynie Świadków Jehowy, „Studia Ełckie” 2009, nr 11.

Ucz się od Wielkiego Nauczyciela, 2003.

Wiara sktania nas do cierpliwości i wytrwałości w modlitwie, „Strażnica” 1997, 15 listopada.

Wiedza, która prowadzi do życia wiecznego, 1995.

Wnikliwe poznawanie Pism, t. I-II, 2006.

Wspaniały finat Objawienia jest bliski!, 1993.

„Zarządzenie” w celu spetnienia zamierzenia Bożego, „Strażnica” 2006, 15 lutego.

Zimniak-Hałajko M., Raj oswojony. Antropologia nowych ruchów religijnych, Gdańsk 2003.

\section{STRESZCZENIE}

Publikacje Świadków Jehowy obfitują w treści proklamowanej przez nich wizji końca świata. Doktryna organizacji wpisuje się w nurt millenarystyczny, a głoszone Królestwo Boże według oficjalnej wykładni rozpoczęło swoje rządy w 1914 roku, kiedy Jezus objął w nim panowanie. Ludzkość zdaniem Towarzystwa Strażnica żyje w „dniach ostatnich”. Aktualna sytuacja na świecie wskazuje, iż należy oczekiwać „,wielkiej rzezi Armagedonu”. Po tych wydarzeniach nastanie „nowe niebo", w którym przebywać będzie 144000 wybranych. Będą oni panowali nad pracami przeprowadzanymi na „nowej ziemi”. Po Tysiącletnim Dniu Sądu Jehowa wypuści Szatana i jego demony, by poddali ludzkość ostatniej próbie. Na koniec zostanie unicestwiona śmierć. Wieczność będzie radosnym przeżywaniem obcowania z Bogiem, ludźmi i zwierzętami. Artykuł nie rości sobie prawa do polemiki międzywyznaniowej czy apologii którejkolwiek konfesji chrześcijańskiej, ma na celu jedynie przekrojową analizę świata post-apo głoszonego przez Świadków Jehowy.

Slowa klucze: apokalipsa, Armagedon, millenaryzm, nowa ziemia, nowe niebo, rzeź, Strażnica, Świadkowie Jehowy 


\section{SUMMARY}

Publications of Jehovah's Witnesses contain numerous references to the vision of the end of the world which they preach. The doctrine of the Organization belongs to millenarian stream and proclaims that the Kingdom of God began in 1914, when Jesus ascended the throne. Mankind, according to the Watch Tower, is living "the last days". The current situation in the world indicates that humanity should expect "great slaughter of Armageddon". 144000 anointed will watch Armageddon from the "new heaven" and they will oversee the works carried out on the "new earth". After the Millennial Day of Judgment, Jehovah will release Satan and his demons who will put humanity to the proof. At the end the death will be destroyed. God, people and animals will be experiencing the joyful communion for eternity. This article does not claim the right to interfaith controversy or apology for any Christian confession, but it merely attempts to comprehensively analyse the postapocalyptic world taught by Jehovah's Witnesses.

Keywords: apocalypse, Armageddon, millenarianism, a new earth, a new heaven, the slaughter, the Watchtower, the Jehovah's Witnesses 